\title{
Hubungan Pengetahuan HIV/AIDS dengan Stigma terhadap Orang dengan HIV/AIDS di Kalangan Remaja 15-19 Tahun di Indonesia (Analisis Data SDKI Tahun 2012)
}

\author{
Relationship HIV/AIDS Knowledge related Stigma towards People Living with HIV/ \\ AIDS among Adolescent 15-19 Years Old in Indonesia (Data Analysis Indonesian \\ Demographic and Health Survey 2012)
}

\author{
Berliana Situmeang ${ }^{a^{*}}$, Syahrizal Syarifb, Renti Mahkotab \\ aProgram Magister Epidemiologi, Fakultas Kesehatan Masyarakat, Universitas Indonesia \\ bDepartemen Epidemiologi, Fakultas Kesehatan Masyarakat, Universitas Indonesia
}

\section{A B STRAK}

Stigma terhadap ODHA menjadi salah satu hambatan paling besar dalam pencegahan, perawatan, pengobatan, dan dukungan HIV/AIDS. Pengetahuan tentang HIV/AIDS mempengaruhi terjadinya stigma terhadap ODHA. Tujuan penelitian ini untuk mengetahui hubungan pengetahuan tentang HIV/AIDS dengan stigma terhadap ODHA di kalangan remaja usia 15-19 tahun di Indonesia. Penelitian ini menggunakan data Survei Demografi dan Kesehatan Indonesia (SDKI) Tahun 2012 dengan disain cross-sectional. Sampel penelitian sebanyak 8.316 orang. Hasil studi menunjukkan $71,63 \%$ remaja mempunyai stigma terhadap ODHA, 49,10\% remaja mempunyai pengetahuan yang kurang tentang HIV. Pengetahuan yang kurang tentang HIV/AIDS berhubungan dengan stigma terhadap ODHA ( $P R=1,210$ 95\% CI: 1,149-1,273) setelah dikontrol oleh keterpaparan media massa. Perlu dilakukan peningkatan pengetahuan tentang HIV/AIDS pada remaja guna mengurangi stigma terhadap ODHA.

Kata kunci : Pengetahuan tentang HIV/AIDS, remaja, stigma

\section{Pendahuluan}

Sejak tahun 1987 di dunia, respon terhadap penyakit HIV/AIDS seperti ketakutan, penolakan, stigma, dan diskriminasi telah muncul bersamaan dengan terjadinya epidemik. Stigma dan diskriminasi telah tersebar secara cepat, menyebabkan terjadinya kecemasan dan prasangka terhadap orang dengan HIV/AIDS (ODHA). ${ }^{1}$

Stigma sering tidak didefinisikan secara eksplisit, melainkan sepintas disebut "tanda aib". 2 Erving Goffman mendefinisikan stigma sebagai atribut yang mendiskreditkan secara signifikan. Penyimpangan label sosial memaksa individu untuk melihat stigma pada dirinya dan orang lain sebagai tidak diinginkan atau didiskreditkan. ${ }^{3}$

Stigma merupakan hambatan utama dalam pencegahan, perawatan, pengobatan, dan dukungan HIV. Ketakutan akan stigma membuat orang cenderung kurang ingin melakukan pemeriksaan HIV dan kurang
A B S TR A C T

Stigma towards people living with HIV/AIDS is one of biggest obstacle in HIV/AIDS prevention, treatment, care, and support. HIV/AIDS knowledge affected stigma towards people living with HIV/AIDS. This study aimed to identify the relationship HIV/AIDS knowledge related stigma towards people living with HIV/AIDS among adolescent 15-19 years old in Indonesia. The study used Indonesian Demographic and Health Survey (IDHS) in 2012 with cross sectional design. Subject of the study were as many as 8.316 persons. The result showed $71,63 \%$ adolescent had stigma towards people living with HIV/AIDS, 49,10\% adolescent had lack of HIV/AIDS knowledge. Lack of HIV/AIDS knowledge were significantly related to stigma towards people living with HIV/AIDS (PR=1,210 95\% CI: 1,149-1,273) after controlling exposure to mass media. Need to improve HIV/AIDS knowledge among adolescent to reduce stigma towards people living with HIV/AIDS.

Keywords: Adolescent, HIV/AIDS knowledge, Stigma

ingin atau menunda mengungkapkan status HIV kepada pasangan. Stigma juga berhubungan dengan penundaan atau penolakan perawatan dan ketidakpatuhan dalam pengobatan HIV.

Sejumlah survei rumah tangga melaporkan meluasnya sikap menstigma diantara masyarakat umum di semua sampel yang diteliti pada keadaan yang berbeda seperti China, US, Hong Kong, Afrika Selatan, Jamaica, Brazil, Nigeria, Thailand, Tanzania, Zimbabwe, Burkina Faso, Zambia, dan Ghana. ${ }^{4}$ Salah satu penelitian di Iran menemukan prevalensi stigma dan persepsi negatif terhadap ODHA berkisar $46-69 \%{ }^{5}$

Di Indonesia terdapat sekitar $62,8 \%$ laki-laki dan perempuan berusia 15-49 tahun yang mendiskriminasi terhadap ODHA. ${ }^{6}$ Analisis Riset Kesehatan Dasar (Riskesdas) dan Survei Sosial Ekonomi Nasional (Susenas) 2007 mengukur sikap stigma dengan empat

*Korespondensi: Berliana Situmeang, Program Magister Epidemiologi, Fakultas Kesehatan Masyarakat, Universitas Indonesia; Email:mutiberliana@gmail.com 
pertanyaan yaitu 1 ) setuju atau tidak tentang merahasiakan, membicarakan dengan anggota keluarga lain, 2) konseling dan pengobatan, 3) mencari pengobatan alternatif, dan 4) mengucilkan bila ada anggota keluarga yang menderita HIV/AIDS. Hasil penelitian menunjukkan $62,7 \%$ responden memperlihatkan sikap yang tidak setuju sehubungan dengan penyakit AIDS.? Penelitian Shaluhiyah, et al menunjukkan hampir separuh dari responden $(49,7 \%)$ memiliki sikap negatif terhadap ODHA. ${ }^{8}$

Stigma masyarakat merupakan fokus dalam penelitian ini karena stigma masyarakat terhadap ODHA memiliki dampak yang besar bagi program pencegahan dan penanggulangan HIV/AIDS termasuk kualitas hidup ODHA. ODHA akan merasa takut melakukan tes HIV karena bila hasilnya terungkap maka mereka akan dikucilkan. Hal ini menyebabkan mereka menunda untuk berobat apabila menderita sakit, yang akan berdampak pada semakin menurunnya kesehatan mereka. ${ }^{8}$

Penelitian stigma terhadap ODHA sudah banyak dilakukan pada masyarakat umum ${ }^{7,9}$, wanita usia subur ${ }^{10}$, tenaga kesehatan ${ }^{11}$, dan remaja ${ }^{1,12}$. Stigma terhadap ODHA umum terjadi di kalangan remaja. Hal ini disebabkan remaja kurang menyadari dan memahami akan bentuk dan efek stigma terhadap populasi beresiko maupun terhadap ODHA. ${ }^{13}$ Penelitian Mutahar dkk menemukan bahwa remaja beresiko 1,5 kali mempunyai stigma terhadap ODHA dibandingkan dengan orang dewasa (9). Usia akan berhubungan dengan perkembangan kognitif, penalaran moral, perkembangan psikoseksual dan sosial. ${ }^{14}$

Stigma remaja menjadi fokus dalam penelitian ini. Banyak faktor yang mempengaruhi terjadinya stigma terhadap ODHA di kalangan remaja salah satunya pengetahuan. Pengetahuan tentang HIV/AIDS sangat mempengaruhi sikap seseorang terhadap ODHA. Stigma muncul berkaitan dengan ketidaktahuan seseorang tentang mekanisme penularan HIV yang dipengaruhi oleh adanya epidemi HIV/AIDS. Kesalahpahaman atau ketidaktahuan tentang HIV sering kali berdampak pada ketakutan terhadap ODHA sehingga menyebabkan penolakan terhadap ODHA. ${ }^{8}$

Beberapa penelitian menemukan hubungan pengetahuan tentang HIV/AIDS dengan sikap stigma terhadap ODHA di kalangan remaja. Penelitian pada siswa SMK di Surabaya menemukan siswa dengan pengetahuan yang rendah mmempunyai stigma yang tinggi terhadap ODHA. ${ }^{12}$ Penelitian pada pelajar SMA 36 menemukan pelajar dengan pengetahuan yang rendah lebih berisiko untuk menstigma ODHA daripada pelajar yang memiliki pengetahuan yang tinggi. ${ }^{1}$ Pengetahuan tentang HIV mempunyai pengaruh dengan sikap menstigma terhadap ODHA. ${ }^{15}$ Pengetahuan medium dan tinggi mempunyai hubungan dengan sikap yang positif terhadap ODHA. ${ }^{16}$ Penelitian pada siswa di Iran menemukan bahwa ada korelasi antara pengetahuan dengan sikap terhadap HIV/AIDS. ${ }^{17}$

Melihat hasil peneltian diatas maka peneliti ingin mengetahui hubungan pengetahuan tentang HIV/AIDS dengan stigma terhadap ODHA di kalangan remaja 1519 tahun di Indonesia setelah dikontrol dengan variabel jenis kelamin, pendidikan, tempat tinggal, keterpaparan media massa, dan pelajaran tentang HIV di sekolah; mengetahui prevalensi stigma terhadap ODHA; serta mengetahui prevalensi pengetahuan yang kurang tentang HIV/AIDS.

\section{Metode Penelitian}

Penelitian ini merupakan penelitian analitik observasional dengan desain cross sectional. Data yang digunakan adalah data sekunder dari Survei Demografi dan Kesehatan Indonesia Komponen Kesehatan Reproduksi Remaja (SDKI KRR) Tahun 2012. Populasi adalah seluruh remaja pria dan wanita usia 15-19 tahun dan belum kawin di Indonesia sebanyak 12.935. Kriteria inklusi sudah pernah mendengar tentang HIV/AIDS dan pernah bersekolah, sedangkan kriteria eksklusi data missing. Melalui perhitungan besar sampel diperoleh sampel minimal sebanyak 784 responden, namun peneliti menggunakan seluruh sampel yang memenuhi kriteria inklusi dan eksklusi sebanyak 8.316 responden.

Pengetahuan HIV/AIDS terdiri atas empat bagian pengetahuan, yaitu: HIV/AIDS, cara penularan, dan cara pencegahan ${ }^{18}$ serta Prevention Mother to Child Transmission (PMTCT). ${ }^{19}$ Pengetahuan dikelompokkan ke dalam dua kategori, yaitu pengetahuan kurang dan pengetahuan cukup. Pengetahuan kurang jika jawaban responden yang benar < 8 dari 12 pertanyaan, sedangkan pengetahuan cukupjika jawaban responden yang benar $\geq 8$ dari 12 pertanyaan. ${ }^{7}$

Stigma terhadap ODHA adalah sikap negatif responden terhadap ODHA. ${ }^{20}$ Stigma dikelompokkan ke dalam dua kategori, yaitu stigma dan tidak stigma. Tidak stigma jika jawaban responden yang benar $\geq$ tiga pertanyaan, sedangkan stigmajika jawaban responden yang benar < tiga pertanyaan dan jawaban yang salah pada semua pertanyaan. ${ }^{10}$ Variabel kovariat terdiri atas 
jenis kelamin, pendidikan, tempat tinggal, keterpaparan media massa, dan pelajaran HIV di sekolah.

Data yang telah diperoleh dari Demographic Health Survey (DHS) dilakukan analisa secara bertahap dari analisa univariat dengan tabulasi distribusi frekuensi masing-masing variabel; analisa bivariat dengan tabulasi silang antara variabel independen, variabel kovariat dengan variabel dependen, dilanjutkan analisa stratifikasi. Analisis multivariat menggunakan cox regression yang dimodifikasi. Hal ini disebabkan prevalensi outcome (stigma terhadap ODHA) di masyarakat $>10 \%$, sehingga lebih tepat jika mengeluarkan prevalence ratio. Cox Regression yang dimodifikasi artinya waktu terjadinya stigma terhadap ODHA dianggap konstan/pada hari yang sama, survival time dalam Cox Regression, ditentukan angka yang sama (1) dengan asumsi stigma terhadap ODHA terjadi pada hari saat survei (wawancara). Uji statistik menggunakan software STATA.

Analisis multivariat dilakukan untuk menemukan permodelan dengan tujuan mengestimasi hubungan variabel independen dengan variabel dependen. Estimasi efek variabel independen terhadap variabel dependen dengan mengontrol semua variabel confounder dan variabel interaksi. Langkah yang dilakukan dengan membuat Hierarchically Well Formulated Model (HWF), lalu uji interaksi kemudian dilanjutkan dengan uji confounding menggunakan Backward Elimination Method. Metode ini mengeluarkan variabel interaksi dan potensial confounderdari permodelan sehingga diperoleh model akhir.
Hasil

Berdasarkan Tabel. 1, diketahui bahwa proporsi karakteristik responden terbesar yaitu perempuan (50,38\%), pendidikan kategori tinggi (73,71\%), tinggal di perkotaan (60,16\%), terpapar media massa (82,24\%), dan terpapar pelajaran HIV di sekolah (88,38\%). Berdasarkan pertanyaan dan jawaban yang benar tentang stigma dalam Tabel. 2, diketahui bahwa 66,6\% responden akan membeli sayuran segar dari penjual atau petani yang diketahui terinfeksi HIV/AIDS, 36,7\% responden tidak akan merahasiakan anggota keluarga yang tertular virus HIV/AIDS, 70,9\% responden bersedia merawat anggota keluarga yang menderita AIDS di rumah, dan 47,4\% responden tetap memperbolehkan guru wanita yang terinfeksi HIV namun tidak kelihatan sakit untuk tetap mengajar di sekolah.

Stigma terhadap ODHA ditentukan dari jawaban yang benar atas pertanyaan yang diberikan kepada responden. Diperoleh hasil 71,63\% responden mempunyai stigma dan 28,37\% responden tidak mempunyai stigma terhadap ODHA. Berdasarkan pertanyaan dan jawaban yang benar tentang pengetahuan HIV/AIDS dalam Tabel. 3, diketahui bahwa 80,6\% responden tahu penampilan seseorang yang telah tertular virus HIV/AIDS tampak sehat, 9,3\% responden tahu cara mengetahui seseorang terinfeksi HIV/AIDS, 8,1\% responden tahu tentang tes HIV secara sukarela yang didahului dengan konseling, 48,5\% responden tahu bahwa virus HIV tidak menular melalui gigitan nyamuk, 79,3\% responden tahu bahwa virus HIV tidak menular melalui guna-guna atau dukun atau santet, 41,6\% responden tahu bahwa virus HIV tidak

Tabel 1. Karakteristik Responden

\begin{tabular}{lcc}
\multicolumn{1}{c}{ Karakteristik } & $\begin{array}{c}\text { Frekuensi } \\
\mathrm{N}=8316\end{array}$ & $\begin{array}{c}\text { Persentase } \\
(\%)\end{array}$ \\
\hline Jenis Kelamin & & \\
$\quad$ Laki-laki & 4.126 & 49,62 \\
Perempuan & 4.190 & 50,38 \\
\hline Pendidikan & & \\
$\quad$ Rendah = SLTP & 2.186 & 26,29 \\
Tinggi > SLTP & 6.130 & 73,71 \\
\hline Tempat Tinggal & & \\
Pedesaan & 3.313 & 39,84 \\
Perkotaan & 5.003 & 60,16 \\
\hline Keterpaparan media massa & & \\
Tidak terpapar & 1.477 & 17,76 \\
Terpapar & 6.839 & 82,24 \\
\hline Pelajaran HIV di sekolah & & \\
Tidak terpapar & 966 & 11,62 \\
Terpapar & 7.350 & 88,38 \\
\hline
\end{tabular}


Tabel 2. Pertanyaan dan Jawaban tentang Stigma terhadap ODHA

\begin{tabular}{|c|c|c|c|c|}
\hline No & Pertanyaan & Jawaban & $\begin{array}{l}\text { Frekuensi } \\
=8.316\end{array}$ & $\begin{array}{c}\text { Persentase } \\
(\%)\end{array}$ \\
\hline 1 & $\begin{array}{l}\text { Apakah saudara akan membeli sayuran segar dari } \\
\text { petani atau penjual yang saudara ketahui terinfeksi } \\
\text { HIV/AIDS? }\end{array}$ & $\begin{array}{l}\text { Ya } \\
\text { Tidak } \\
\text { Tidak tahu }\end{array}$ & $\begin{array}{r}2.450 \\
5.536 \\
330 \\
\end{array}$ & $\begin{array}{r}29,5 \\
66,6 \\
4,0 \\
\end{array}$ \\
\hline 2 & $\begin{array}{l}\text { Jika salah satu anggota keluarga tertular virus } \\
\text { HIV/AIDS, apakah saudara akan merahasiakannya? }\end{array}$ & $\begin{array}{l}\text { Ya } \\
\text { Tidak } \\
\text { Tidak tahu/tidak } \\
\text { yakin }\end{array}$ & $\begin{array}{r}4.809 \\
3.049 \\
458\end{array}$ & $\begin{array}{r}57,8 \\
36,7 \\
5,5\end{array}$ \\
\hline 3 & $\begin{array}{l}\text { Jika salah satu anggota keluarga saudara menderita } \\
\text { AIDS, apakah saudara bersedia merawatnya di rumah } \\
\text { saudara? }\end{array}$ & $\begin{array}{l}\text { Ya } \\
\text { Tidak } \\
\text { Tidak tahu/tidak } \\
\text { yakin/tergantung }\end{array}$ & $\begin{array}{r}5.900 \\
1.891 \\
525\end{array}$ & $\begin{array}{r}70,9 \\
22,7 \\
6,3\end{array}$ \\
\hline 4 & $\begin{array}{l}\text { Jika seorang guru wanita diketahui tertular virus } \\
\text { HIV/AIDS tapi tidak kelihatan sakit, menurut pendapat } \\
\text { saudara apakah ia sebaiknya diperbolehkan tetap } \\
\text { mengajar di sekolah? }\end{array}$ & $\begin{array}{l}\text { Ya } \\
\text { Tidak } \\
\text { Tidak tahu/tidak } \\
\text { yakin/ tergantung }\end{array}$ & $\begin{array}{r}3942 \\
3723 \\
651\end{array}$ & $\begin{array}{r}47,4 \\
44,8 \\
7,8\end{array}$ \\
\hline
\end{tabular}

Tabel 4. Hubungan Pengetahuan tentang HIV/AIDS dengan Stigma terhadap ODHA

\begin{tabular}{|c|c|c|c|c|c|}
\hline \multirow[t]{2}{*}{ Pengetahuan } & \multicolumn{2}{|c|}{ Stigma terhadap ODHA } & \multirow[t]{2}{*}{ Jumlah } & \multirow[t]{2}{*}{ PR 95\% CI } & \multirow[t]{2}{*}{$p$-value } \\
\hline & Stigma & Tidak Stigma & & & \\
\hline Kurang & $\begin{array}{c}3.216 \\
(78,77 \%)\end{array}$ & $\begin{array}{c}867 \\
(21,23 \%)\end{array}$ & $\begin{array}{c}4.083 \\
(100 \%)\end{array}$ & $\begin{array}{c}1,216 \\
(1,183-1,250)\end{array}$ & 0,000 \\
\hline Cukup & $\begin{array}{c}2.741 \\
(64,75 \%) \\
\end{array}$ & $\begin{array}{c}1.492 \\
(35,25 \%) \\
\end{array}$ & $\begin{array}{c}4.233 \\
(100 \%) \\
\end{array}$ & reff & \\
\hline
\end{tabular}

menular melalui makan sepiring dengan orang yang terinfeksi HIV, 94\% responden tahu bahwa virus HIV menular melalui penggunaan jarum suntik yang sama secara bergantian, 73,7\% responden tahu bahwa pencegahan penularan virus HIV dengan membatasi hubungan seks dengan seseorang yang tidak mempunyai pasangan, 60\% responden tahu bahwa pencegahan penularan virus HIV dengan menggunakan kondom, 79,2\% responden tahu penularan virus HIV dari ibu ke anak selama kehamilan, $67,9 \%$ responden tahu penularan virus HIV dari ibu ke anak selama melahirkan, dan 78,9\% responden tahu penularan virus HIV dari ibu ke anak selama menyusui.

Pengetahuan tentang HIV ditentukan dari jawaban yang benar atas pertanyaan yang diberikan kepada responden. Diperoleh hasil 49,10\% responden yang memiliki pengetahuan kurang dan 50,90\% responden yang memiliki pengetahuan cukup tentang HIV/AIDS.

Berdasarkan Tabel. 4, diketahui bahwa nilai PR sebesar 1,216 (95\% CI: 1,183-1,250). Hal ini menunjukkan bahwa kelompok responden yang memiliki pengetahuan yang kurang tentang HIV/AIDS 1,216 kali lebih berisiko mempunyai stigma terhadap 38
ODHA dibandingkan dengan kelompok responden yang memiliki pengetahuan yang cukup. Pengetahuan tentang HIV/AIDS dengan stigma terhadap ODHA berhubungan secara bermakna.

Berdasarkan Tabel. 5, diketahui bahwa variabel pendidikan, tempat tinggal, keterpaparan media massa, dan pelajaran HIV di sekolah berhubungan secara bermakna dengan stigma terhadap ODHA. Jenis kelamin tidak memiliki hubungan yang bermakna.

Pada analisis bivariat, dilakukan stratifikasi untuk mengetahui apakah variabel kovariat memberikan efek modifikasi (interaksi) atau merupakan variabel potensial confounder. Dalam menilai interaksi dengan menilai perbedaan PR antar strata, PR crude, dan PR adjusted (Mentel-Haenze) variabel kovariat dan dibuktikan menggunakan p-value uji statistik homogenity Mente/Haenzel. Jika $p$-value <0,05, berarti variabel kovariat tersebut heterogen atau berinteraksi terhadap stigma terhadap ODHA. Namun jika p-value $>0,05$, berarti variabel kovariat tersebut homogen atau tidak berinteraksi terhadap stigma terhadap ODHA. Menilai confounding dengan menilai perbedaan PR. Jika PR $>10 \%$, berarti variabel kovariat tersebut merupakan potensial confounder, demikian sebaliknya. 
Tabel 3. Pertanyaan dan Jawaban tentang Pengetahuan HIV/AIDS

\begin{tabular}{|c|c|c|c|c|}
\hline No & Pertanyaan & Jawaban & $\begin{array}{l}\text { Frekuensi } \\
=8.316\end{array}$ & $\begin{array}{l}\text { Persentase } \\
(\%)\end{array}$ \\
\hline \multirow[t]{3}{*}{1} & \multirow{3}{*}{$\begin{array}{l}\text { Apakah mungkin seseorang yang penampilannya tampak } \\
\text { sehat ternyata ia telah tertular virus HIV/AIDS? }\end{array}$} & $\mathrm{Ya}$ & 6.704 & 80,6 \\
\hline & & Tidak & 788 & 9,5 \\
\hline & & Tidak tahu & 824 & 9,9 \\
\hline \multirow[t]{16}{*}{2} & \multirow{16}{*}{$\begin{array}{l}\text { Bagaimana cara mengetahui seseorang terinfeksi } \\
\text { HIV/AIDS? }\end{array}$} & Fisik $(A)$ & 2.240 & 26,9 \\
\hline & & Perilaku orang (B) & 167 & 2,0 \\
\hline & & Tes darah $(C)$ & 776 & 9,3 \\
\hline & & Lainnya (X) & 392 & 4,7 \\
\hline & & $A B$ & 303 & 3,6 \\
\hline & & $A B C$ & 79 & 0,9 \\
\hline & & $A B C X$ & 1 & 0,0 \\
\hline & & $A B X$ & 11 & 0,1 \\
\hline & & $A C$ & 348 & 4,2 \\
\hline & & $A C X$ & 15 & 0,2 \\
\hline & & $A X$ & 178 & 2,1 \\
\hline & & $B C$ & 19 & 0,2 \\
\hline & & $B C X$ & 1 & 0,0 \\
\hline & & $B X$ & 16 & 0,2 \\
\hline & & $C X$ & 69 & 0,8 \\
\hline & & Tidak tahu (Z) & 3.701 & 44,5 \\
\hline \multirow[t]{2}{*}{3} & \multirow{2}{*}{$\begin{array}{l}\text { Apakah saudara tahu tentang adanya tes HIV/AIDS secara } \\
\text { sukarela yang didahului dengan konseling yang dikenal } \\
\text { dengan VCT yaitu Voluntary Counseling and Testing? }\end{array}$} & $\mathrm{Ya}$ & 673 & 8,1 \\
\hline & & Tidak & 7.643 & 91,9 \\
\hline \multirow[t]{3}{*}{4} & \multirow{3}{*}{$\begin{array}{l}\text { Bisakah seseorang tertular virus HIV/AIDS melalui gigitan } \\
\text { nyamuk? }\end{array}$} & $\mathrm{Ya}$ & 2.959 & 35,6 \\
\hline & & Tidak & 4.032 & 48,5 \\
\hline & & Tidak tahu & 1.325 & 15,9 \\
\hline \multirow[t]{3}{*}{5} & \multirow{3}{*}{$\begin{array}{l}\text { Bisakah seseorang tertular virus HIV/AIDS karena diguna- } \\
\text { guna atau didukuni atau disantet? }\end{array}$} & $\mathrm{Ya}$ & 655 & 7,9 \\
\hline & & Tidak & 6.597 & 79,3 \\
\hline & & Tidak tahu & 1.064 & 12,8 \\
\hline \multirow[t]{3}{*}{6} & \multirow{3}{*}{$\begin{array}{l}\text { Bisakah seseorang tertular virus HIV/AIDS dengan cara } \\
\text { makan sepiring dengan orang yang sudah terkena virus } \\
\text { HIV/AIDS? }\end{array}$} & $\mathrm{Ya}$ & 3.865 & 46,5 \\
\hline & & Tidak & 3.460 & 41,6 \\
\hline & & Tidak tahu & 991 & 11,9 \\
\hline \multirow[t]{3}{*}{7} & Bisakah seseorang tertular virus HIV/AIDS karena & $\mathrm{Ya}$ & 7.820 & 94,0 \\
\hline & \multirow{2}{*}{ menggunakan jarum suntik yang sama secara bergantian? } & Tidak & 166 & 2,0 \\
\hline & & Tidak tahu & 330 & 4,0 \\
\hline \multirow[t]{3}{*}{8} & \multirow{3}{*}{$\begin{array}{l}\text { Bisakah seseorang mengurangi kemungkinan tertular virus } \\
\text { HIV dan AIDS dengan membatasi hubungan seks dengan } \\
\text { seseorang yang tidak mempunyai pasangan? }\end{array}$} & $\mathrm{Ya}$ & 6.129 & 73,7 \\
\hline & & Tidak & 1.127 & 13,6 \\
\hline & & Tidak tahu & 1.060 & 12,7 \\
\hline \multirow[t]{3}{*}{9} & \multirow{3}{*}{$\begin{array}{l}\text { Bisakah seseorang mengurangi kemungkinan tertular virus } \\
\text { HIV/AIDS dengan cara memakai kondom setiap melakukan } \\
\text { hubungan seks? }\end{array}$} & $\mathrm{Ya}$ & 4.986 & 60,0 \\
\hline & & Tidak & 1.649 & 19,8 \\
\hline & & Tidak tahu & 1.681 & 20,2 \\
\hline \multirow[t]{3}{*}{10} & \multirow{3}{*}{$\begin{array}{l}\text { Apakah virus penyebab AIDS dapat ditularkan oleh } \\
\text { seorang ibu ke anaknya selama kehamilan? }\end{array}$} & $\mathrm{Ya}$ & 6.584 & 79,2 \\
\hline & & Tidak & 663 & 8,0 \\
\hline & & Tidak tahu & 1.069 & 12,9 \\
\hline \multirow[t]{3}{*}{11} & \multirow{3}{*}{$\begin{array}{l}\text { Apakah virus penyebab AIDS dapat ditularkan oleh } \\
\text { seorang ibu ke anaknya saat melahirkan? }\end{array}$} & $\mathrm{Ya}$ & 5.649 & 67,9 \\
\hline & & Tidak & 1.115 & 13,4 \\
\hline & & Tidak tahu & 1.552 & 18,7 \\
\hline 12 & Apakah virus penyebab AIDS dapat ditularkan oleh & $\mathrm{Ya}$ & 6.563 & 78,9 \\
\hline & seorang ibu ke anaknya selama menyusui? & Tidak & 632 & 7,6 \\
\hline & & Tidak tahu & 1.121 & 13,5 \\
\hline
\end{tabular}


Tabel 5 Hubungan Variabel Kovariat dengan Stigma terhadap ODHA

\begin{tabular}{|c|c|c|c|c|c|}
\hline \multirow[t]{2}{*}{ Variabel } & \multirow[t]{2}{*}{ Kategori } & \multicolumn{2}{|c|}{ Stigma terhadap ODHA } & \multirow[t]{2}{*}{ PR 95\% CI } & \multirow[t]{2}{*}{ p-value } \\
\hline & & Stigma & Tidak Stigma & & \\
\hline \multirow[t]{2}{*}{ Jenis kelamin } & Laki-laki & $\begin{array}{c}2.942 \\
(71,30 \%)\end{array}$ & $\begin{array}{c}1.184 \\
(28,70 \%) \\
\end{array}$ & reff & \multirow[t]{2}{*}{0,508} \\
\hline & Perempuan & $\begin{array}{c}3.015 \\
(71,96 \%) \\
\end{array}$ & $\begin{array}{c}1.184 \\
(28,70 \%) \\
\end{array}$ & $\begin{array}{c}1,009 \\
(0,982-1,037) \\
\end{array}$ & \\
\hline \multirow[t]{2}{*}{ Pendidikan } & Rendah & $\begin{array}{c}1.633 \\
(74,70 \%) \\
\end{array}$ & $\begin{array}{c}553 \\
(25,30 \%) \\
\end{array}$ & $\begin{array}{c}1,059 \\
(1,028-1,090)\end{array}$ & \multirow[t]{2}{*}{0,0002} \\
\hline & Tinggi & $\begin{array}{c}4.324 \\
(70,54 \%)\end{array}$ & $\begin{array}{c}1.806 \\
(29,46 \%) \\
\end{array}$ & reff & \\
\hline \multirow[t]{2}{*}{ Tempat Tinggal } & Pedesaan & $\begin{array}{c}2.436 \\
(73,53 \%)\end{array}$ & $\begin{array}{c}877 \\
(26,47 \%)\end{array}$ & $\begin{array}{c}1,044 \\
(1,016-1,073)\end{array}$ & \multirow[t]{2}{*}{0,0018} \\
\hline & Perkotaan & $\begin{array}{c}3.521 \\
(70,38 \%) \\
\end{array}$ & $\begin{array}{c}1.482 \\
(29,62 \%) \\
\end{array}$ & reff & \\
\hline \multirow[t]{2}{*}{$\begin{array}{l}\text { Keterpaparan } \\
\text { Massa }\end{array}$} & Tidak Terpapar & $\begin{array}{c}1.137 \\
(76,98 \%)\end{array}$ & $\begin{array}{c}340 \\
(23,02 \%)\end{array}$ & $\begin{array}{c}1,092 \\
(1,058-1,127)\end{array}$ & \multirow[t]{2}{*}{0,000} \\
\hline & Terpapar & $\begin{array}{c}4.820 \\
(70,48 \%)\end{array}$ & $\begin{array}{c}2.019 \\
(29,52 \%) \\
\end{array}$ & reff & \\
\hline \multirow[t]{2}{*}{ Pelajaran HIV di sekolah } & Tidak Terpapar & $\begin{array}{c}736 \\
(76,19 \%)\end{array}$ & $\begin{array}{c}230 \\
(23,81 \%)\end{array}$ & $\begin{array}{c}1,072 \\
(1,032-1,114)\end{array}$ & \multirow[t]{2}{*}{0,0008} \\
\hline & Terpapar & $\begin{array}{c}5.221 \\
(71,03 \%)\end{array}$ & $\begin{array}{c}2.129 \\
(28,97 \%) \\
\end{array}$ & reff & \\
\hline
\end{tabular}

Tabel 6. Analisis Multivariat

\begin{tabular}{lccc}
\hline \multicolumn{1}{c}{ Variabel } & PR & $95 \%$ CI & p value \\
\hline Pengetahuan & 1,204 & $1,143-1,269$ & 0,000 \\
\hline Jenis Kelamin & 0,989 & $0,940-1,041$ & 0,671 \\
\hline Pendidikan & 1,014 & $0,955-1,076$ & 0,657 \\
\hline Tempat Tinggal & 1,019 & $0,967-1,073$ & 0,491 \\
\hline Keterpaparan Media Massa & 1,056 & $0,988-1,128$ & 0,108 \\
\hline Pelajaran HIV di sekolah & 1,010 & $0,931-1,095$ & 0,816 \\
\hline
\end{tabular}

Setelah dilakukan analisis stratifikasi pengetahuan tentang HIV dengan stigma terhadap ODHA, ditemukan bahwa variabel jenis kelamin, pendidikan, tempat tinggal, keterpaparan media massa, dan pelajaran HIV di sekolah tidak memberikan efek modifikasi (interaksi) dan bukan merupakan confounder.

Pada analisis analisis multivariat kembali dilakukan uji interaksi dan uji confounding. Sebelumnya pada analisis stratifikasi, tidak ada variabel kovariat yang berinteraksi. Namun, variabel pendidikan, tempat tinggal, keterpaparan media, dan pelajaran HIV secara substansi berinteraksi sehingga variabel tersebut dimasukkan ke dalam analisis multivariat untuk dilakukan uji interaksi. Setelah dilakukan uji interaksi, keempat variabel tersebut tidak berinteraksi sehingga dikeluarkan dari model. Tabel. 6 menunjukan model awal hubungan variabel independen dan variabel potensial confounderterhadap variabel dependen.

Uji confounding dengan mengeluarkan variabel satu per satu dimulai dari variabel yang mempunyai $p$ value tertinggi. Berdasarkan uji tersebut, tidak ada variabel yang secara statistik merupakan variabel confounder sehingga variabel tersebut dapat dikeluarkan dari model. Namun peneliti mempertimbangkan variabel keterpaparan media massa menjadi variabel confounder sehingga dimasukkan ke dalam model akhir.

Setelah dilakukan uji confounding, diperoleh model akhir yaitu responden yang memiliki pengetahuan yang kurang 1,210 (95\% CI: 1,149-1,273) kali lebih berisiko mempunyai stigma terhadap ODHA dibandingkan dengan responden yang mempunyai pengetahuan yang cukup tentang HIV/AIDS setelah dikontrol keterpaparan media massa.

\section{Diskusi}

Berdasarkan hasil penelitian terhadap 8.316 responden diketahui bahwa responden yang 
mempunyai stigma terhadap ODHA sebesar 71,63\%. $\mathrm{Hal}$ ini sejalan dengan Analisis Riskesdas dan Susenas Tahun 2007 yang mengukur sikap stigma yang menunjukkan bahwa sebagian besar responden memperlihatkan sikap yang tidak setuju sehubungan dengan dengan penyakit AIDS (62,7\%) dan sisanya (37,3\%) memperlihatkan sikap yang setuju tentang penyakit AIDS.?

Berdasarkan pertanyaan stigma terhadap ODHA, diketahui bahwa 66,6\% responden tidak akan membeli sayuran segar dari penjual atau petani yang diketahui terinfeksi HIV/AIDS. Seperti diketahui orang yang terinfeksi HIV (penjual sayuran) akan mengalami infeksi oportunistik yang terkait dengan infeksi HIV. Hal ini kemungkinan yang menyebabkan orang enggan membeli sayuran karena takut tertular infeksi tersebut. ${ }^{9}$

Lebih dari setengah responden akan merahasiakan anggota keluarga yang tertular HIV (57,8\%). Hal ini kemungkinan disebabkan mereka khawatir jika status HIV positif anggota keluarganya diketahui, orang lain akan menunjukkan beragam perlakuan tidak adil terhadap mereka seperti dijauhi dan diejek sampai dengan pembatasan hak mereka. ${ }^{9}$

Mayoritas responden bersedia merawat anggota keluarga yang menderita AIDS di rumah (70,9\%). Hal ini sejalan dengan penelitian Letamo, mayoritas responden bersedia merawat. Hal ini menunjukkan bahwa responden mempunyai sikap yang lebih toleran ketika orang yang terinfeksi HIV adalah anggota keluarganya. Namun, masih terdapat sekitar 22,7\% responden yang tidak bersedia merawat. Jumlah tersebut lebih tinggi dibandingkan dengan penelitian Letamo, dari 4.147 responden, hanya 11\% yang tidak bersedia merawat anggota keluarga yang sakit. ${ }^{20}$

Mengenai guru wanita yang terinfeksi HIV namun tidak kelihatan sakit, 47,4\% responden tetap memperbolehkan tetap mengajar di sekolah. Jumlah tersebut lebih rendah dibandingkan penelitian Letamo, sebesar 57,9\% responden tetap memperbolehkan guru yang terinfeksi HIV untuk tetap mengajar. Responden yang tidak memperbolehkan guru yang terinfeksi untuk tetap mengajar mencerminkan adanya perbedaan, pengecualian, dan larangan terhadap ODHA. Hal ini didasarkan pada serostatus guru wanita tersebut. ${ }^{20}$

Berdasarkan pertanyaan pengetahuan tentang HIV/AIDS, diketahui bahwa hanya 9,3\% responden yang tahu bahwa tes darah adalah cara mengetahui seseorang terinfeksi HIV/AIDS dan 8,1\% responden yang tahu adanya tes HIV/AIDS secara sukarela yang didahului dengan konseling. Hal ini sejalan dengan
Analisis Riskesdas 2010, dari 28.898 responden hanya 10,1\% yang mengetahui tes sukarela HIV/AIDS dan konseling. ${ }^{21}$

Masih terdapat pemahaman yang keliru tentang penularan virus HIV. Responden yang tahu bahwa virus HIV tidak menular melalui gigitan nyamuk sebesar 48,5\% dan responden yang tahu bahwa virus HIV tidak menular melalui makan sepiring dengan ODHA sebesar 41,6\%. Hal ini sejalan dengan dengan penelitian Sudikno dkk, $47,7 \%$ responden tahu penularan tidak melalui gigitan nyamuk dan 50,5\% responden tahu penularan tidak melalui makan sepiring dengan ODHA. Berdasarkan jawaban tentang pengetahuan HIV/AIDS, dapat disimpulkan bahwa mayoritas responden belum tahu cara pemeriksaan jika terinfeksi HIV, adanya tes HIV yang didahului dengan konseling dan dilakukan secara sukarela serta cara penularan virus HIV khususnya melalui gigitan nyamuk dan makan sepiring dengan ODHA.

Hasil penelitian ini menemukan 49,10\% responden memiliki pengetahuan yang kurang tentang HIV/AIDS. Hanya 26 responden yang mampu menjawab keseluruhan pertanyaan dengan benar $(0,3 \%)$. Persentase tersebut masih lebih kecil dibandingkan dengan hasil penelitian KPA. Persentase remaja (15-24 tahun) yang mampu menjawab dengan benar cara-cara pencegahan penularan HIV/AIDS serta menolak pemahaman yang salah mengenai penularan HIV/AIDS sebesar $14,3 \%$.

Berdasarkan hasil analisis multivariat diperoleh nilai PR sebesar 1,210 (95\% CI: 1,149-1,273). Hal ini menunjukkan bahwa kelompok responden yang memiliki pengetahuan yang kurang tentang HIV/AIDS 1,210 kali lebih berisiko mempunyai stigma terhadap ODHA dibandingkan dengan kelompok responden yang memiliki pengetahuan yang cukup. Hal ini sejalan dengan penelitian pada siswa SMK Surabaya, pengetahuan yang rendah tentang HIV/AIDS memiliki stigma yang tinggi terhadap ODHA $(p=0,000) .{ }^{12}$ Penelitian di kalangan pelajar SMA menemukan bahwa tingkat pengetahuan yang rendah tentang HIV/AIDS lebih berisiko untuk menstigma ODHA daripada tingkat pengetahuan yang tinggi $(p=0,000, O R=3,37,95 \% C I$ 2,32-4,88). ${ }^{1}$

Dalam penentuan sikap, pengetahuan, pikiran, keyakinan, dan emosi memegang peranan penting. ${ }^{14}$ Pengetahuan tentang HIV/AIDS sangat mempengaruhi sikap seseorang terhadap penderita HIV/AIDS. ${ }^{8}$ Stigma dan diskriminasi terhadap ODHA muncul berkaitan 
dengan ketidaktahuan tentang mekanisme penularan HIV8,22,23, perkiraan risiko tertular yang berlebihan melalui kontak biasa dan sikap negatif terhadap kelompok sosial yang tidak proporsional yang dipengaruhi oleh epidemik HIV/AIDS. Hal ini didukung dengan penelitian di Botswana yang menggambarkan bahwa ketidakpahaman cara penularan HIV sering menimbulkan stigma dan diskriminasi terhadap ODHA. ${ }^{1}$ Penelitian di Afrika Selatan juga menemukan kesimpulan yang sama, pengetahuan penularan HIV menjadi penyebab penting terjadinya stigma. ${ }^{24}$ Kesalahpahaman atau kurangnya pengetahuan masyarakat tentang HIV/ AIDS berdampak pada ketakutan masyarakat terhadap ODHA, sehingga muncul penolakan terhadap ODHA. ${ }^{8}$

Pada penelitian ini, lebih setengah responden dengan pengetahuan yang cukup menunjukkan stigma terhadap ODHA. Semakin tinggi/cukup pengetahuan seseorang maka perilaku/sikapnya akan lebih baik, namun dalam penelitian ini hal tersebut tidak berlaku. Hal ini mungkin disebabkan semakin seseorang mengetahui tentang HIV/AIDS, maka mereka akan lebih waspada terhadap HIV/AIDS. Jika seseorang tidak mengetahui tentang HIV, mereka akan menganggap penyakit ini sama dengan penyakit lain pada umumnya. ${ }^{9}$

Penelitian ini memiliki beberapa keterbatasan

yang mempengaruhi hasil penelitian, yaitu penelitian ini menggunakan disain penelitian cross-sectional sehingga tidak dapat melihat hubungan sebab akibat (exposure harus mendahului outcome); penelitian ini menyesuaikan ketersediaan variabel dalam SDKI; pertanyaan-pertanyaan yang tersedia terbatas dan kurang mendalam; pertanyaan untuk menilai stigma merupakan pertanyaan hypothetical. Pertanyaan tersebut mungkin mengarah kepada bias disebabkan kemungkinan responden memberikan jawaban yang dapat diterima secara sosial, dibandingkan dengan refleksi bagaimana/apa yang mereka rasakan; kemungkinan telah terjadi bias seleksi disebabkan adanya missing data sebanyak 2.510 responden dengan populasi eligible berjumlah 8.316 responden sehingga diketahui non participation rate sebesar 30\%. Pada penelitian ini, tidak diketahui karakteristik responden yang hilang tersebut (berasal dari kelompok eksposure atau non eksposure) sehingga tidak dapat diketahui bias seleksi ini menyebabkan underestimate atau overestimate; kemungkinan terjadi recall bias (bias mengingat kembali) ketika responden ditanyakan pertanyaan mengenai keterpaparan media massa dan pelajaran HIV di sekolah.

\section{Simpulan dan Saran}

Prevalensi remaja yang mempunyai stigma terhadap ODHA sebesar 71,63\%, prevalensi remaja yang memiliki pengetahuan kurang tentang HIV/AIDS sebesar 49,10\%. Pengetahuan yang kurang 1,210 (95\% CI: 1,149-1,273) kali lebih berisiko mempunyai stigma terhadap ODHA dibandingkan dengan pengetahuan yang cukup tentang HIV/AIDS setelah dikontrol keterpaparan media massa

Kementerian Kesehatan diharapkan bekerja sama dengan Kementerian Pendidikan dan Kebudayaan untuk menyusun pelajaran dengan topik penyakit menular seksual termasuk HIV/AIDS untuk dapat dimasukkan ke dalam kurikulum sekolah serta selalu melakukan kegiatan sosialisasi pencegahan penyakit HIV/AIDS terutama mengenai mekanisme penularan HIV dan Voluntary Counseling and Testing (VCT).

\section{Referensi}

1. Sosodoro O, Emilia O, Wahyuni B. Hubungan Pengetahuan Tentang HIV/AIDS dengan Stigma Orang dengan HIV/AIDS di kalangan Pelajar SMA. Ber Kedokt Masy [Internet]. 2012

2. Mahajan AP, Sayles JN, Patel VA, Remien RH, Ortiz D, Szekeres G, et al. Stigma in the HIV/AIDS epidemic: A review of the literature and recommendations for the way forward. NIH Public Access [Internet]. 2010 [cited 2017 Mar 22];

3. Goffman E. STIGMA Notes on the Management of Spoiled Identity. USA: Prentice-Hall, Inc; 1963.

4. Macquarrie K, Ekhaus T, Nyblade L. HIV-related Stigma and Discrimination: A Summary of Recent Literature. 2009.

5. Masoudnia E. Public perceptions about HIV/AIDS and discriminatory attitudes toward people living with acquired immunodeficiency syndrome in Iran. J Soc Asp HIV/AIDS. 2015;12.

6. UNAIDS. Country factsheets Indonesia. 2015.

7. Oktarina O, Hanafi F, Budisuari MA. Hubungan Antara Karakteristik Responden, Keadaan Wilayah Dengan Pengetahuan, Sikap Terhadap HIV/AIDS Pada Masyarakat Indonesia. Bul Penelit Sist Kesehat [Internet]. 2009 [cited 2017 Mar 14];12(4).

8. Shaluhiyah Z, Musthofa SB, Widjanarko B. Stigma Masyarakat terhadap Orang dengan HIV/AIDS. Kesmas Natl Public Heal J [Internet]. 2015 [cited 2017 Mar 14];9(4):333-9.

9. Mutahar R, Najmah Y. Determinants of Indonesian People Attitudes Towards People Living with HIV/AIDS (PLWHA). Int J Public Heal Res Spec Issue [Internet]. 2011 [cited 2017 Mar 14];

10. Sari EP. Determinan yang Mempengaruhi Stigma terhadap Orang dengan HIV/AIDS (ODHA) pada wanita pernah kawin usia 15-49 tahun di Indonesia. Universitas Indonesia; 2015.

11. Harapan H, Feramuhawan S, Kurniawan H, Anwar S, Andalas M, Hossain MB. HIV-related stigma and discrimination: a 
study of health care workers in Banda Aceh, Indonesia. Med J Indones [Internet]. 2013 Feb 1 [cited 2017 Mar 14];22(1):22.

12. Parut, Aristo A. Hubungan Pengetahuan tentang HIV/AIDS dengan Stigma terhadap ODHA pada Siswa Kelas XI SMK VI Surabaya. J NERS LENTERA [Internet]. 2016 [cited 2017 Mar 14];4(2):106-13.

13. St Xavier's college, ICRW, UNDP, STRIVE. Integrating a youthbased stigma and discrimination reduction curriculum in higher education CASE STUDY St Xavier 's College. 2013.

14. Notoatmodjo S. Promosi Kesehatan \& Ilmu Perilaku. Jakarta: Rineka Cipta; 2007.

15. Sohn A, Park S. HIV/AIDS Knowledge, Stigmatizing Attitudes, and Related Behaviors and Factors that Affect Stigmatizing Attitudes against HIV/AIDS among Korean Adolescents. Osong public Heal Res Perspect [Internet]. 2012 Mar [cited 2017 Mar 14];3(1):24-30.

16. Thanavanh B, Harun-Or-Rashid M, Kasuya H, Sakamoto J. Knowledge, attitudes and practices regarding HIV/AIDS among male high school students in Lao People's Democratic Republic. J Int AIDS Soc [Internet]. 2013 Mar 11 [cited 2017 Mar 16];16(1).

17. Tavoosi A, Zaferani A, Enzevaei A, Tajik P, Ahmadinezhad Z. Knowledge and attitude towards HIV/AIDS among Iranian student. BMC Public Health. 2004;

18. Hinduan ZR, Suherman H, Pinxten WJL, Alisjahbana B, Hospers HJ. HIV-related knowledge and attitudes among Indonesian prison officers. Int J Prison Health. 2013;9:92102.

19. Wang W, Alva S, Wang S. HIV-related knowledge and behaviors among people living with HIV in eight high HIV prevalence countries in sub-Saharan Africa [Internet]. 2012 [cited 2017 Mar 14].

20. Letamo G. Prevalence of and Factors Associated with HIV/ AIDS-related Stigma and Discriminatory Attitudes in Botswana. J Heal Popul Nutr [Internet]. 2003 [cited 2017 Mar 15];21:347-57.

21. Pratiwi NL, Basuki H. Analisis Hubungan Pengetahuan Pencegahan HIV/AIDS dan Perilaku Seks Tidak Aman PAda remaja Usia 15-24 tahun Di Indonesia. Bul Penelit Sist Kesehat [Internet]. 2011 [cited 2017 Mar 14];14:192-202.

22. Herek GM. Thinking about AIDS and stigma: A psychologist's perspective. J Law Med Ethics Winter [Internet]. 2002 [cited 2017 Mar 16];30(4).

23. Herek GM, Capitanio JP, Widaman KF. HIV-related stigma and knowledge in the United States: prevalence and trends, 1991-1999. Am J Public Health [Internet]. 2002 Mar [cited 2017 Mar 14];92(3):371-7. Available from: http:// www.ncbi.nlm.nih.gov/pubmed/11867313

24. Maughan-Brown BG. Attitudes towards people with HIV/ AIDS: Stigma and its determinants amongst young adults in Cape Town, South Africa. South African Rev Sociol [Internet]. 2006 Jul [cited 2017 Mar 14];37(2):165-88. 